\title{
Mechanical Properties of Co-Cr-Mo Alloy in Dependence in the Composition and Production
}

Kateřina Nová ${ }^{1}$, Pavel Novák ${ }^{1}$, D. Dvorský ${ }^{1}$, J. Zýka²

${ }^{1}$ University of Chemistry and Technology, Prague, Department of Metals and Corrosion Engineering, Technická 5, 166 28 Prague 6, Czech Republic, E-mail: kety.n@seznam.cz

${ }^{2}$ UJP PRAHA a.s., Nad Kamínkou1345, 15610 Praha-Zbraslav, Czech Republic

The aim of this work was studying the effect of the composition and production on mechanical and tribological properties of cobalt alloys. Co-Cr-Mo alloy began to be used for manufacturing dental implants, but nowadays they are successfully used for the production of orthopaedic implants thanks to better wear resistance than is offered by titanium implants. However, there is still ongoing effort to even more improve the wear resistance and other properties of cobalt based alloy. The aim of this research was to find a suitable combination between composition and production, which would increase the wear resistance, keeping the other mechanical properties at least at the same level. Standard Co-Cr-Mo alloy and also $\mathrm{Co}-\mathrm{Cr}$-Mo alloy with various alloying elements, specifically $\mathrm{Nb}$, Ti in an amount $5 \mathrm{wt} \%$, were prepared by casting and also mechanical alloying followed by compacting method "Spark Plasma Sintering". The influence of production route as well as influence of alloying elements on the microstructure, mechanical and tribological properties were observed. Based on the obtained results, the CoCr-Mo-Ti alloy production by casting seems to be most suitable, because the addition of titanium has greatly improved the wear resistance. However, it is necessary to perform many other tests, especially tests of corrosion resistance and biocompatibility.

Keywords: cobalt alloy, mechanical properties, biomaterial, type of production, wear resistance

\section{Acknowledgement}

This research was financially supported by Czech Science Foundation, project No. P108/12/G043.

\section{References}

[1] GÜlSOY, H. Ö.; ÖZGÜN, Ö.; BILKETAY, S. (2016).Powder injection molding of Stellite 6 powder: Sintering, microstructural and mechanical properties. In: Materials Science and Engineering A, Vol. 651, pp. 914-924. Elsevier. Turkey.

[2] MARTI, A. (2000).Cobalt-base alloys used in bone surgery. In:Injury, Vol. 31, No.4, pp. D18-D21. Elsevier.

[3] CAWLEY, J., et al. (2003).A tribological study of cobalt chromium molybdenum alloys used in metal-on-metal resurfacing hip arthroplasty. In: Wear, Vol. 255, No. 7-12,pp. 999-1006. Elsevier. UK.

[4] SAWANGRAT, C., et al. (2014).Application of Harmonic Struture Design to Biomedical Co-Cr-Mo alloy for Improved Mechanical Properties.In: Materials Transaction, Vol. 55, No. 1, pp. 99-105.

[5] BELlEFONTAINE, G. (2010).The corrosion of CoCrMo alloys for biomedical applications. In:Doctoral dissertation.University of Birmingham. UK.

[6] MATKOVIĆ, T., MATKOVIĆ,P., MALINA, J. (2004).Effects of Ni and Mo on the microstructure and some other properties of Co-Cr dental alloys. In: Journal of alloys and compounds, Vol. 366, No. 1-2,pp. 293-297. Elsevier. Croatia.

[7] ZUPANČIČ, R., LEGAT,A., FUNDUK, N. (2007).Electrochemical and mechanical properties of cobaltchromium dental alloy joints.In: Materials and technology, Vol. 41, No. 6,pp. 295-300.Institute of Metals and Technology. Ljubljana. Slovenia.

[8] NOVAK, P. (2014). CZ Patent 305703.

[9] NOVÁK, P., et al. (2015). New Composite Materials Based on NiTi. In: Manufacturing technology. Vol. 15, No. 4, pp. 644-647. UJEP Ústínad Labem.Czech Republic. 